NBER WORKING PAPER SERIES

\title{
MARKET UNDERREACTION \\ TO OPEN MARKET SHARE REPURCHASES
}

\author{
David Ikenberry \\ Josef Lakonishok \\ Theo Vermaelen
}

Working Paper No. 4965

\section{NATIONAL BUREAU OF ECONOMIC RESEARCH 1050 Massachusetts Avenue \\ Cambridge, MA 02138 \\ December 1994}

We appreciate the comments of Amir Barnea, Louis Chan, Bala Dharan, Narashimhan Jegadeesh, Steve Kaplan, Tim Loughran, Matt Maher, Robert McDonald, Bill Nelson, Tim Opler, Graeme Rankine, Jay Ritter, Andrei Shleifer, Richard Shockley, David Smith, Kay Stice, Robert Vishny, $J F E$ editor Jerold Warner and an anonymous referee. We also extend thanks to Eugene Fama for providing us with monthly factor returns. This paper has been presented at the 1994 NBER Behavioral Finance meeting, the 1994 NBER Corporate Finance meeting, the Spring 1994 CRSP Seminar on the Analysis of Security Prices, the 1994 Western Finance Association meetings, the 1994 European Q-group meetings in Lausanne, the 1994 European Finance Association meetings in Brussels, the University of Chicago, the University of Houston, Texas A\&M University and Rice University. This paper is part of NBER's research program in Corporate Finance. Any opinions expressed are those of the authors and not those of the National Bureau of Economic Research.

(c) 1994 by David Ikenberry, Josef Lakonishok and Theo Vermaelen. All rights reserved. Short sections of text, not to exceed two paragraphs, may be quoted without explicit permission provided that full credit, including $\odot$ notice, is given to the source. 


\title{
MARKET UNDERREACTION TO OPEN MARKET SHARE REPURCHASES
}

\begin{abstract}
We examine long-run firm performance following open market share repurchase announcements which occurred during the period 1980 to 1990 . We find that the average abnormal four-year buy-and-hold return measured after the initial announcement is 12.1 percent. For "value" stocks, companies more likely to be repurchasing shares because of undervaluation, the average abnormal return is 45.3 percent. For repurchases announced by "glamour" stocks where undervaluation is less likely to be an important motive, no positive drift in abnormal returns is observed. Thus, at least with respect to value stocks, the market errs in its initial response and appears to ignore much of the information conveyed through repurchase announcements.
\end{abstract}

David Ikenberry

Department of Economics

Rice University

PO Box 1892

Houston, TX 77251
Josef Lakonishok

Department of Economics

University of Illinois

330 Commerce West

1206 South Sixth Street

Champaign, IL 61820

Theo Vermaelen

INSEAD

Boulevard de Constance

77305 Fontainebleau

FRANCE 


\section{Introduction}

Corporations distribute substantial sums of wealth to shareholders by repurchasing their own stock. From 1980 to 1990 , the aggregate value of stock repurchased on the NYSE, ASE and NASDAQ was about one-third of the value distributed as cash dividends. Toward the end of the 1980 's, the dollars involved in repurchases increased substantially, becoming nearly half the amount paid as cash dividends. Framed differently, the dollar value of stock repurchases announced between 1985 and 1993 is nearly three times larger than that raised through IPOs. ${ }^{1}$ In 1994 , stock buybacks continue at a record pace as more than $\$ 45$ billion were announced in the first nine months of the year. Firms can reacquire shares either through fixed-price offers or through open market transactions. Historically, managers have chosen the latter approach by wide margins. For example, 90 percent of the dollar value of all share repurchases announced between 1985 and 1993 were to be completed through open market transactions. In this paper, we examine the performance of firms which chose this approach for repurchasing shares.

The literature provides a lengthy list of motivations for why corporations might repurchase their own shares: capital structure adjustment, takeover defense, signalling, excess cash distribution, substitution for cash dividends, and wealth expropriation from bondholders. While all of these reasons are plausible, signalling has emerged as one of the most prevalent explanations (Vermaelen (1981), Dann (1981), Asquith and Mullins (1986), Ofer and Thakor (1987), and Constantinides and Grundy (1989)). The Traditional Signalling Hypothesis (or TSH) is motivated by asymmetric information between the marketplace and a firm's managers. If in management's assessment the firm is undervalued, they might choose to buy back stock. Making such an announcement is thus argued to serve as a valuable signal to a less informed marketplace. If markets respond efficiently, prices should adjust immediately in an unbiased manner. The new equilibrium price should fully reflect the

\footnotetext{
${ }^{1}$ From 1985 to 1993 , the total value of all announced share repurchases recorded by Securities Data Company was $\$ 334$ billion (excluding REITs and closed-end funds). The comparable dollar value of initial public offerings over the same period was $\$ 114$ billion.
} 
"true" value of the new information, and no wealth transfer should occur between long-term shareholders and those selling shares to the firm.

When managers are asked why they repurchase shares on the open market, the most commonly cited reason is "undervaluation" and that their shares represent a "good investment," two reasons seemingly consistent with the TSH (Baker, Gallagher and Morgan (1981), Dann (1983), Wansley, Lane and Sarkar (1989)). Yet paradoxically, if prices adjust instantaneously, how can the stock be a good investment for long-term shareholders? In an efficient market, the stock should no longer be undervalued after the announcement, thus eliminating the motivation to undertake the repurchase.

However managers typically do not announce that they are canceling a repurchase program. This would suggest that the initial market reaction is too low. Given that the average market reaction is only on the order of 3 percent, this would indeed seem to be the case. It seems hardly plausible that managers would, first, have the ability to recognize such small valuation errors and, second, choose to react to such minor discrepancies. Placed in perspective, 3 percent is not that much greater than the daily standard deviation of returns for many stocks. If managers are reacquiring shares because of mispricing, it is likely that they perceive substantially greater valuation errors. For example, in October 1993, Midland Resources Inc., a U.S. based oil and gas concern, announced an open market share repurchase for 5 percent of its shares. At the announcement, the chairman is quoted as saying, "If you look at the amount of our reserves, we think (our stock) should be trading for about twice its current value. What it boils down to is, if you can buy a dollar for 50 cents, why not buy it?"

We hypothesize that the market treats repurchase announcements with skepticism, leading prices to adjust slowly over time. We refer to this as the Underreaction Hypothesis (or $U H$ ). Evidence consistent with this hypothesis has been documented in a study on fixed-price tender offer 
stock repurchases. Lakonishok and Vermaelen (1990) find that prices on average remain at bargain levels for at least two years. Other examples of delayed market reactions include IPOs (Ritter (1991)), mergers (Agrawal, Jaffe and Mandelker (1992)), proxy contests (Ikenberry and Lakonishok (1993)) and spinoffs (Cusatis, Miles and Woolridge (1993)). In what is essentially the mirror image of a stock repurchase, Loughran and Ritter (1994) observe a sluggish response by the market to seasoned equity offerings.

Is it possible that the market fully incorporates the information conveyed through an open market repurchase? If so, we should observe that stock prices following the announcement are unbiased and that long-run performance is not above average. Or alternatively, do managers in fact really know what they are doing and are correct in their assessment that their stock is a good investment, even after the repurchase announcement. These fundamental questions motivate the remainder of this paper.

We examine a sample of 1,239 open market share repurchases announced between January 1980 and December 1990 by firms whose shares traded on the NYSE, ASE or NASDAQ. Similar to the findings reported in earlier research, the average market response to the announcement of an open market share repurchase is 3.5 percent. Furthermore, this initial reaction is consistent with several predictions of the TSH. For example, the market reacts more favorably to announcements made by low market capitalization firms and by firms announcing large repurchase programs.

Yet the most striking finding of this paper is that the information conveyed by open market share repurchases is largely ignored. Managers of firms that repurchase their own shares appear to have been correct, on average, in assuming that they can buy shares at bargain prices to the benefit of their long-term shareholders. Beginning in the month following the repurchase announcement, the average buy-and-hold return over the next four years is more than 12 percent above that of a control portfolio. 
If undervaluation is an important motive overall, it should be particularly important for outof-favor stocks, which tend to have high book-to-market ratios. Yet surprisingly, the announcement return is similar across all book-to-market groups. Over the long run, however, the largest abnormal returns following buyback announcements are observed in high book-to-market firms. The average return over the next four years for a buy-and-hold portfolio of these stocks is 45.3 percent above that of a control portfolio of similar size and book-to-market firms. For low book-to-market firms, no abnormal performance is observed in long-run returns.

The remainder of the paper is organized as follows. In section 2 , we describe the data and our sample. Issues regarding performance measurement and significance tests are discussed in section 3. In section 4 , we examine daily returns surrounding the announcement of open market share repurchases. In section 5 , we examine long-run performance. In section 6 , we explore the determinants of long-run performance. In section 7 , we check the robustness of our findings. Conclusions are provided in section 8 .

\section{Data}

Our sample was formed by identifying all announcements reported in the Wall Street Journal from January 1980 through December 1990 stating that a firm intended to repurchase its own common stock through open market transactions. We examine all open market share repurchase announcements without regard to whether the programs were actually completed. We further require that these firms be included on the daily CRSP NYSE and ASE tape or daily CRSP NASDAQ tape, as well as the Annual Industrial Compustat file at the time of the announcement. For most of our analysis, we exclude all announcements made in the fourth quarter of 1987 . Following the 1987 crash, 777 NYSE, ASE and NASDAQ firms announced either new or increased share repurchase programs totalling over $\$ 45$ billion, largely in response to their low post-crash share prices. 
Although we also examined announcements made during this period, these cases are not included in the results we report in order that this unusual period not dominate our study.

Table 1 shows the distribution of the repurchase announcements by year, the average percentage of shares repurchased and the dollar value of the repurchase announcements. These repurchases, if fully completed, would have totalled $\$ 142$ billion. Over the entire 11-year period, sample companies announced repurchases for 6.6 percent of their outstanding shares on average. This percentage was generally rising over our sample period. Table 1 also shows the distribution of announcements according to firm size. Size deciles were determined in the month prior to the announcement based on market equity value relative to the universe of all NYSE and ASE stocks covered by both CRSP and Compustat. Our sample has a bias favoring larger firms. Nearly onethird of our sample is ranked in the two largest size deciles.

\section{Methodology}

\subsection{Performance measurement}

We examine both short-term returns surrounding the announcement as well as long-term performance following the announcement. Short-term performance is calculated over various windows from 20 days before to 10 days following the announcement. The results are not overly sensitive to the benchmark used when abnormal returns are calculated over such short intervals. Thus we report results using a straightforward approach by calculating abnormal returns with respect to the CRSP equal-weighted index of NYSE and ASE firms. We also calculated short-term performance with respect to other benchmarks including the CRSP value-weighted index as well as a size-based approach, but the results were essentially the same.

Care must be taken when calculating long-run performance because the findings can be sensitive to the procedures used (see Chopra, Lakonishok and Ritter (1992)). In this paper, we 
pursue two different approaches. The first is the more common technique based on cumulative abnormal returns, or CARs, relative to some benchmark. The second approach calculates long-run abnormal performance assuming a buy-and-hold strategy. For both of these methods, abnormal returns are calculated relative to four benchmarks: the CRSP equal- and value-weighted indices of NYSE and ASE firms, a size-based benchmark and finally a size and book-to-market based benchmark. This last benchmark is motivated by the recent work of Fama and French (1992 and 1993) and Lakonishok, Shleifer and Vishny (1994). ${ }^{2}$

\subsubsection{The CAR Approach}

Under the CAR approach, abnormal returns are calculated each month relative to a benchmark and then aggregated over time. This procedure assumes monthly rebalancing with sample firms receiving equal portfolio weights. Furthermore, it also assumes that returns are not compounded. Although takeovers and bankruptcies reduce the number of firms in the sample as event-time progresses, these cases are not excluded from our analysis. Abnormal performance is measured using the returns to all companies existing in a given event month, even those that eventually depart the sample.

Calculating performance relative to the CRSP equal- and value-weighted indices is straightforward and requires no further discussion. To calculate abnormal returns adjusted for size, we form ten size-based portfolios at the end of April each year using all NYSE and ASE firms jointly on CRSP and Compustat. Monthly returns are calculated for these ten portfolios over the next year, assuming equal-weighting. These returns are then used as benchmarks to measure abnormal performance. Each month, the abnormal returns are calculated for each repurchase firm relative to its

\footnotetext{
2 To distinguish "value" stocks from "glamour" stocks, a variety of ratios aside from book-to-market exist. For example, Lakonishok, Shleifer and Vishny (1994) find that classifying stocks by cash-flow-to-price produces an even larger spread in returns than does sorting by book-to-market. However, sorting on the basis of cashflow-to-price poses some difficulties when cash flow becomes negative. Hence we classify firms using book-tomarket ratios.
} 
respective size benchmark. CARs are then calculated by averaging across all repurchase firms each month and summing over time.

To calculate abnormal returns controlling for both size and book-to-market, each of the ten size deciles discussed above is further sorted by book-to-market ratio into quintiles. Quintile 1 contains the 20 percent of all stocks in a given size decile with the lowest book-to-market ratios. At the other extreme are the 20 percent of firms within a given size decile with the highest ratios. This sorting results in 50 benchmark portfolios for each month (10 size deciles $\mathrm{x} 5$ book-to-market quintiles). As is done when we adjust only for size, all firms are ranked at the end of each April for the following 12 months. We assume a four-month lag in reporting financial results to avoid any look-ahead bias. Thus for companies whose fiscal year ends in December, the book equity value will be recent. For firms with fiscal year-ends following December yet preceding April, we calculate book-to-market ratios using book equity values from the prior year. Abnormal performance for each of the repurchase firms is then calculated using the appropriate size and book-to-market benchmark. ${ }^{3}$

\subsubsection{The buy-and-hold approach}

The results using the CAR approach should be regarded as descriptive in nature since they do not represent a realistic investment strategy. However, our second approach is more consistent with a feasible strategy. We assume an equal-weighted buy-and-hold investment in all repurchase firms beginning in the month following the announcement and continuing for 12 months. After one year, the portfolio is rebalanced, thus reducing the possibility that a small set of firms will dominate the

\footnotetext{
${ }^{3}$ As a check on the validity of this approach, we examined whether a randomly drawn sample with the same size and book-to-market characteristics would also produce abnormal performance. We did this by pooling the announcement dates of all repurchase firms along with their corresponding size and book-to-market rankings. We then formed a random sample by arbitrarily drawing from this pool 2,500 times and assigning the announcement date to a randomly chosen NYSE or ASE firm that had the same size and book-to-market ranking at that point in time. In each of the $\mathbf{4 8}$ months following the "event" month, the cumulative abnormal return for this random sample was less than \pm 1.5 percent using the size and book-to-market approach and was always within one standard error. When performance was measured using the CRSP equal- or value-weighted index of NYSE and ASE stocks, CARs were in excess of two standard errors in many months.
} 
return calculations. ${ }^{4}$ The multi-year total return to this investment strategy is calculated by compounding average annual returns over time.

To calculate abnormal performance, we form four benchmarks, similar in spirit to the four benchmarks created using the CAR approach, but calculated in a manner consistent with the buy-andhold investment strategy. To save space, we only report results using the size and book-to-market benchmark approach. To form the reference portfolio, all firms on the NYSE and ASE and also carried on Compustat are sorted each month into one of 50 size and book-to-market portfolios as described earlier. Beginning in the next month, the one-year buy-and-hold return is calculated for each firm in a given portfolio. The equal-weighted average of all annual returns in a given portfolio is then used as a benchmark return for firms ranked in that particular size and book-to-market rank at that point in time. Thus, this procedure leads us to compute annual buy-and-hold returns for each of the 50 benchmark portfolios each calendar month.

In addition to annual returns, we also measure compounded abnormal performance for two, three and four years following the repurchase announcement. To calculate a two-year abnormal return, we take the difference between the compounded two-year return to repurchase firms, assuming rebalancing after the first year, and that of the reference portfolio. ${ }^{5}$ Abnormal performance in years three and four is treated similarly.

\subsection{Significance testing}

Significance levels are calculated for daily, monthly and annual returns. For daily cumulative

\footnotetext{
${ }^{4}$ If a firms departs the sample prematurely, we assume the investment is sold at the last available price on CRSP and that the proceeds from this sale are reinvested for the remainder of the year in that firm's benchmark portfolio. At the end of the year, the portfolio is rebalanced using only the surviving firms. Firms used to calculate benchmark returns were treated similarly.

${ }^{5}$ The size and book-to-market ranking of a particular firm may change from year to year. To accommodate this, we allow the benchmark used to compute abnormal performance to change over time as well.
} 
abnormal returns, we use the "event-time" methodology as outlined by Brown and Warner (1985). Here, standard errors are estimated from the time series of daily portfolio abnormal returns calculated over days -250 to -21 relative to the repurchase announcement. Autocorrelation in daily abnormal returns in this study is low. Corrections we made for autocorrelation had essentially no impact on the results. Thus, we present $t$-tests that assume zero autocorrelation. To estimate significance levels for monthly CARs, we also use an event-time methodology as described by Brown and Warner (1980). Standard errors are calculated in a similar fashion, using months -36 to +48 relative to the repurchase announcements. As before, we calculate $t$-tests assuming time independence since corrections for autocorrelation had essentially no impact on the analysis.

For a variety of reasons, the approach described above is not appropriate when examining annual buy-and-hold or compounded multi-year returns. For example, estimating standard errors using an event-time approach requires a "reasonable" number of annual observations. Many firms simply do not have a long history of returns. Moreover, for those firms where the availability of returns is not an issue, assuming that the return distribution is stable over such a long period of time is questionable. Furthermore, since buy-and-hold returns are compounded rather than cumulated over time, multi-year standard errors cannot be simply inferred from annual standard errors. And finally, the skewness of long-run returns and clustering of observations in time also pose problems for traditional significance tests.

Therefore, statistical inference of annual buy-and-hold and compounded multi-year returns is done via bootstrapping as was recently applied by Brock, Lakonishok and LeBaron (1992) in their examination of technical trading strategies. Under this approach we generate the empirical distribution of annual buy-and-hold and multi-year compounded abnormal returns under the null hypothesis. Specifically, for each repurchase announcement in our sample, we randomly select with replacement a firm listed on the NYSE or ASE with the same size and book-to-market ranking at that 
point in time. We treat this randomly chosen company as if it had announced a repurchase on the same day as the corresponding repurchase firm. This matching process continues until each firm in our repurchase sample is represented in this "pseudo" portfolio. This portfolio will have one randomly drawn firm for each actual repurchase firm matched in time with similar size and book-tomarket characteristics. After forming a single pseudo portfolio, we estimate long-run performance in the same manner we did for the repurchase sample. This yields one observation of the abnormal performance obtained from randomly forming a portfolio with the same characteristics as our repurchase sample. This entire process is repeated such that we have 1,000 pseudo portfolios and thus 1,000 abnormal return observations. This provides us with an empirical approximation of the distribution of abnormal returns drawn under the null model specific to our sample. The null hypothesis is rejected at the $\alpha$ percent level if the abnormal return obtained from the repurchase sample is greater than the (1- $\alpha)$ percentile abnormal return observed in the empirical distribution. The appeal of the bootstrap approach is that it avoids many of the problems that plague $t$-tests regarding assumptions over normality, stationarity and time independence of observations. Departures from these basic assumptions are especially worrisome for returns calculated over long intervals such as a year or more. To the extent that these problems exist in long-run returns, they are also present in our pseudo portfolios and thus are not concerning.

We also examine long-run firm performance by time-period as well as by book-to-market ranking at the time of the repurchase announcement. The associated p-values are estimated by repeating the entire bootstrap procedure for each sub-sample. For example, when we report long-run performance for high book-to-market stocks announcing buybacks, the associated p-values are derived from the distribution of abnormal returns obtained from the 1,000 pseudo portfolios specifically matched to this particular sub-sample. 


\section{The market reaction to open market share repurchase announcements}

Table 2 provides a comprehensive analysis of short-term abnormal returns surrounding repurchase announcements in our sample. Looking at repurchase announcements overall, there is a downward drift in abnormal returns prior to the announcement measured from days -20 to -3 totalling -3.07 percent. The average market reaction measured from two days before through two days following publication of the announcement in the Wall Street Journal is 3.54 percent. Following the announcement, returns, on average, appear to be quite similar to those of the market. This evidence is similar to the findings reported by other researchers examining repurchase announcements (for example, Vermaelen (1981) and Comment and Jarrell (1991)).

The initial market reaction changes only slightly across the three sub-periods; decreasing from 4.25 percent between 1980 and 1983 to 2.33 percent in the period 1987 to 1990 . Consistent with the TSH, larger share repurchase programs are received more favorably by the market. For example, the mean announcement period abnormal return for programs which are for more than 10 percent of outstanding shares is 4.51 percent. For those programs which are for less than 2.5 percent of outstanding shares, the average market reaction is 2.58 percent.

Table 2 also reports short-term announcement returns according to the reason provided in the abstract of the Wall Street Journal Index. Some caution should be exercised here since it is difficult to assess management's true motivation for the repurchase by reading such abbreviated press statements. Furthermore, no reason is mentioned for nearly 85 percent of the cases. Yet for the few cases in which a reason is mentioned, undervaluation is a prominent theme. For the 38 cases in which undervaluation was specifically mentioned, both the negative drift prior to the announcement ( -5.52 percent) and the market reaction at the announcement ( 5.31 percent) are comparatively large.

The next to last panel in Table 2 shows short-term performance by firm size. The market reaction shows clear differences across size groups. Firms ranked in the two smallest size deciles 
show the highest abnormal returns on average: 8.19 percent, more than double that observed overall. Those in the two largest size deciles exhibit an abnormal return of only 2.09 percent. If firm size is viewed as a proxy for information asymmetries, the observed relationship between size and abnormal returns is consistent with the TSH.

Separating the various motivations for undertaking an open market stock repurchase is difficult. One approach is to examine announcement returns with respect to book-to-market ratios. Firms with low book-to-market ratios are likely to be repurchasing shares for reasons other than undervaluation. At the other extreme, repurchases announced by firms with high book-to-market ratios, or value stocks, are more likely to have undervaluation as a primary motivation. Yet we see in Table 2 that the market reaction to the repurchase announcement is similar across the five book-tomarket quintiles. The average market reaction for firms in quintile 1 (glamour stocks) is 3.36 percent, while it is 3.56 percent for firms in quintile 5 (value stocks).

To sort out more clearly the nature of announcement returns, we also regressed announcement returns on various firm characteristics. To control for the possibility that positive announcement returns reflect mean reversion arising from negative returns observed prior to the announcement, we also included the CAR from days -20 to -3 in the regressions. Although not reported here, the results are consistent with the evidence reported in Table 2 even after controlling for the impact of return reversals. As the percentage of shares announced for repurchase increases, the market reaction increases and as firm size increases, announcement returns decline substantially. Yet as before, the regression results provide no indication that the book-to-market ratio has any impact on the market reaction to repurchase announcements.

\section{The long-term performance of firms repurchasing their own shares}

Figure 1 plots CARs up to 48 months following a repurchase announcement using four 
different benchmarks. These CARs are calculated beginning in month 1 and thus exclude the initial market reaction to the announcement. The picture which emerges is that firms which announce an open market stock repurchase tend to perform well in the long run. Focusing on size-adjusted returns, the CAR from month 1 to 36 is 8.69 percent $(t=2.50)$. Following month 36 , abnormal returns are close to zero. This positive drift cannot be explained by the book-to-market effect. When returns are adjusted for both size and book-to-market, the CAR from month 1 to 36 is nearly the same, 8.17 percent $(t=2.37)$. These findings suggest that the market underreacts to the announcement of a repurchase. Focusing only on the initial market reaction ( 3.5 percent), about 70 percent of the total valuation impact is ignored.

The picture is slightly different when the CRSP value-weighted index is used as a benchmark. Although post-announcement abnormal returns are positive, they are lower than when either the sizeonly or size and book-to-market benchmarks are used, and are about half that observed using the CRSP equal-weighted index. This occurs because large firms substantially outperformed smaller firms during the latter portion of our sample period.

Although the CAR approach is straightforward to understand, the analysis is best regarded as descriptive in nature. A more appealing approach is the buy-and-hold procedure described earlier. The results using such an approach are reported in Table $3 .^{6}$ The left-hand side of this table shows mean annual returns from buying an equal-weighted portfolio of repurchasing firms beginning in the month following the announcement and for the subsequent four years. To the right of this column are returns to the reference portfolio calculated using the size and book-to-market benchmarks corresponding to the repurchase sample. The right side of Table 3 reports total compounded buy-andhold returns up to four years, allowing for annual rebalancing. Results are also presented for two

\footnotetext{
${ }^{6}$ Because book-equity values were not available for some firms, the number of firms in this table differs slightly from that reported in Table 2 .
} 
sub-periods; announcements made in years 1980 to 1985 and those made in years 1986 to 1990 .

The average return in the first year following the repurchase announcement is 20.80 percent, 2.04 percent more than the reference portfolio. This difference in annual returns increases to 2.31 percent and 4.59 percent in years 2 and 3. As was observed in Figure 1, the phenomenon appears to dissipate by year 4 as the difference is close to zero. Although not reported in the tables, we also examined performance in year 5 and again found abnormal returns close to zero ( -0.13 percent). Turning to compounded returns, the difference in performance after four years is substantial, 12.14 percent. The p-value associated with this abnormal return is .012 . In Figure 2, we plot the empirical distribution of four-year compounded abnormal returns under the null hypothesis based on our bootstrapping procedure using 1,000 replications. From this figure, we see that the probability that a random portfolio will exhibit abnormal performance as high as our repurchase sample is remote. In our case, only 12 pseudo portfolios out of a total of 1,000 demonstrated compounded abnormal returns higher than 12.14 percent after four years. Focusing on year 3 , the difference in compounded returns between the repurchase and the reference portfolio is 12.60 percent with a corresponding pvalue of .000 , meaning that none of the 1,000 pseudo portfolios performed as well. Apparently, investing in companies that announce buybacks is a profitable long-run strategy, at least over the decade of the 1980 s.

When attention is turned to the two sub-periods, some differences in long-run performance are apparent. In the early sub-period, 1980-1985, the compounded abnormal return is 16.02 percent in year 3. This value decreases slightly to 14.55 in year 4 . In both years, abnormal performance is statistically significant at traditional confidence levels. In the later sub-period, 1986-1990, compounded abnormal performance after year 3 is 9.21 percent and is highly significant. In year 4 , compounded abnormal performance increases slightly to 10.24 percent, yet is only marginally significant. 


\section{Undervaluation as a motive for open market share repurchases}

\section{A. Long-term performance by book-to-market quintile}

Our analysis to this point has examined the long-run performance of all firms announcing their intention to repurchase shares. Although the evidence suggests that undervaluation is an important factor leading companies to repurchase their shares, other motives also exist. An interesting question is whether long-run performance is more pronounced in cases more clearly motivated by undervaluation.

Therefore in Table 4, we examine long-run firm performance by book-to-market ranking at the time of the repurchase announcement. As mentioned earlier, repurchases by high book-to-market companies are more likely to be driven by undervaluation. However we observed earlier in Table 2 that the market's initial reaction is not associated with book-to-market rankings. If these stocks are indeed undervalued, then positive abnormal returns should be observed even after adjusting for bookto-market effects. The reason for this is similar to that documented by Lakonishok, Shleifer and Vishny (1994): not all high book-to-market stocks are "truly" out-of-favor. Using a two-way classification procedure, they find that high book-to-market stocks which performed well in the past substantially underperform high book-to-market stocks with poor past performance ("truly" out-offavor stocks). If high book-to-market firms announcing stock buybacks are truly out-of-favor, then they too should outperform a benchmark which only adjusts for book-to-market effects in general.

Annual buy-and-hold abnormal returns adjusted for size and book-to-market are reported in Table 4. Focusing on value stocks in quintile 5 , the results are striking. Here, the compounded fouryear buy-and-hold return is 135.91 percent, 45.29 percent above the reference portfolio return comprised of similar size and book-to-market companies. The associated p-value here is .000 meaning that none of the 1,000 pseudo portfolios specifically formed for this sub-sample performed as 
well. ${ }^{7}$ This extraordinary performance is not limited to a small number of cases. Value stocks comprise 26.2 percent of the sample measured on a dollar-weighted basis. To check the robustness of our findings for value stocks, we also calculated long-run performance for this group on a year-byyear basis. In each case, four-year compounded abnormal returns were positive.

Although one might expect quintile 5 stocks in our sample to be the most undervalued at the time of the announcement, long-run abnormal performance is not exclusive to this sub-set. For example, firms in quintile 4 (which constitute 21.3 percent of our sample when measured on a dollarweighted basis) also show average abnormal performance of 12.47 percent after year 3 with an associated p-value of .058 . As one moves from value stocks toward glamour stocks, long-run performance declines. For example, the mean four-year compounded abnormal return for glamour stocks in quintile 1 is slightly negative, -4.31 percent.

The sharp contrast in long-term performance between value and glamour companies suggests that the motivations for undertaking a share repurchase differ across companies. In the case of high book-to-market firms, undervaluation appears to be a major factor. The puzzle is why the market treats the announcements made by these firms with such skepticism. For glamour firms, the motivation for repurchasing shares is more ambiguous. Some of these firms might undertake a repurchase as a means of "supporting their share price," a reason frequently mentioned in the press. In addition, it is possible that the managers of glamour firms are more prone to be affected by hubris leading them to believe that their shares are underpriced and thus choosing to repurchase stock.

To investigate further the impact of the book-to-market variable, we examine the determinants of long-run performance following announcements. We do this by estimating a cross-sectional

\footnotetext{
${ }^{7}$ As we observed overall, the positive drift observed in value stocks repurchasing shares is generally confined to the first three years. By year 4 , the difference between this portfolio and its respective benchmark, though positive ( 3.23 percent), is not significant using traditional confidence levels. As a check, we also examined performance in year 5 and found that the difference narrows further to 2.06 percent.
} 
regression where the four-year compounded abnormal return is the dependent variable. If a firm leaves the sample mid-way through the four-year period, we assume that the stock is sold and that the proceeds are reinvested in the reference portfolio so that four-year performance is available for all companies in our sample. The independent variables are the book-to-market quintile ranking, the size decile ranking, the fraction of shares they intend to repurchase and the three-year abnormal return prior to the repurchase to control for mean reversion in returns. Although we do not report these results here, book-to-market is by far the strongest variable related to long-run performance.

\section{Robustness}

In this section, we examine the robustness of our findings, especially with respect to repurchases announced by value stocks where abnormal returns are particularly high. Specifically, we explore three issues: 1) the impact of takeovers, 2) performance measurement, and 3) multiple announcements.

\subsection{The impact of takeovers}

It is possible that the abnormal performance observed for firms repurchasing shares is caused by an unusually high incidence of takeovers. To the extent that this is not anticipated by the market, the upward drift may be a consequence of takeover premiums. This might be a particularly relevant issue for value stocks whose relatively low prices may have been attractive to bidding firms. To investigate this possibility, we compared long-run performance overall with that observed using only firms that survived at least four years following the announcement. Three-year compounded abnormal performance for announcements made between 1980 and 1988 is 13.0 percent. Of this group, 84.4 percent survived. Focusing only on survivors, the three-year compounded abnormal return diminishes to 6.7 percent, though still significant.

For repurchase firms ranked in the highest book-to-market quintile, returns also diminish 
when we focus on survivors, yet abnormal performance is still extremely positive. Here compounded three-year abnormal performance falls from 39.7 percent using all eligible firms to 31.6 percent when only survivors are examined. The survival rate in this group ( 86.2 percent) differs little from that observed overall. Thus, the presence of takeovers in our sample would not appear to explain the abnormal returns of firms repurchasing shares, particularly with respect to cases in which book-tomarket ratios are high and long-run performance is so positive.

\subsection{Performance Measurement}

Fama and French (1993) suggest a three-factor model to measure abnormal performance. The first factor is the excess return to a value-weighted portfolio of NYSE, ASE and NASDAQ stocks. The second is a size factor measured as the difference in returns between a value-weighted portfolio of small stocks (firms with market equity value below that of the median NYSE stock) and one of large stocks (firms with market equity value above that of the median NYSE stock). The third factor is a book-to-market factor measured as the difference in returns between a value-weighted portfolio of firms ranked among the 30 percent of NYSE stocks with the highest book-to-market ratios and one containing those firms ranked among the 30 percent of NYSE stocks with the lowest ratios.

To use this procedure, we form a time series of monthly returns in calendar-time. Specifically, we buy companies at the end of the month in which a repurchase announcement is made and keep them for 36 months. The composition of the portfolio changes over time. Each month the portfolio is rebalanced, new firms are added as they make announcements and old firms are removed. This results in a time series of monthly returns for announcements between 1980 and 1990 . The main puzzle is the extraordinary performance obtained for value stocks. Thus, we again form portfolios based on book-to-market rankings at the time of the repurchase announcement. Excess monthly returns are then regressed on the three Fama-French factors. We exclude from our analysis returns during the first six months of 1980 . In these initial months, the number of firms in each 
portfolio is small. The alpha from each regression is a monthly estimate of abnormal performance similar in spirit to Jensen's alpha, but controlling for size and book-to-market factors in addition to the overall market. This approach differs from the buy-and-hold procedure in several respects. First, returns are rebalanced monthly, thus the abnormal performance measured under this approach is less representative of a realistic investment strategy. Second, this procedure assumes that the coefficients are stable over time, thus implying that the characteristics of the portfolios are also not changing.

The results are reported in Table 5. The alpha obtained in the first regression using book-tomarket quintile 1 stocks (glamour stocks) is -0.30 percent per month, though not significant from zero at traditional confidence levels. The alpha obtained using book-to-market quintile 5 stocks (value stocks) is 0.43 percent per month and is highly significant. The spread in performance between high and low book-to-market firms repurchasing their shares is 0.73 percent per month, or 8.76 percent per year, and is consistent with our earlier findings. Gibbons, Ross and Shanken (1989) suggest an F-statistic to more formally test whether the alphas produced in these regressions are jointly equal to zero. The F-statistic associated with our analysis is 2.642 with an associated probability level of .973 , thus rejecting the hypothesis that the alphas are jointly equal to zero.

Although not reported here, we also applied the Fama-French three-factor model in a RATS (Returns Across Time and Securities) framework which aligns returns in event-time. This approach relaxes assumptions regarding parameter stability. Thus alphas are calculated monthly for 36 months following the repurchase announcement. The difference in alphas between high and low book-tomarket stocks averages 0.69 percent per month, a result similar to the calendar-time approach.

\subsection{Multiple Announcements}

Nearly one-fourth of our cases are firms which had a repurchase announcement in the prior three years. We examined whether these cases were somehow affecting our results. Firms making repeat repurchase announcements do show strong performance. Compounded abnormal performance 
after three years for these firms is 15.0 percent. Yet repeat announcements also cannot explain the abnormal performance we observe overall. Focusing on those firms announcing buybacks for the first time or those that have not made an announcement in three years, compounded three-year abnormal performance is still impressive, 11.3 percent.

This finding is true of high book-to-market stocks as well. Here, firms making their first repurchase announcement in three years show compounded abnormal performance three years after the announcement of 26.3 percent. High book-to-market stocks making a repeat announcement have compounded abnormal performance after three years of 56.4 percent. If managers seek to acquire shares from the market at bargain prices, rather than announce one large share repurchase, they might instead announce a series of smaller announcements stretching over several years. Furthermore, if the market underreacts to the first announcement, managers with strong conviction that their shares remain undervalued may choose to make additional announcements.

\section{Conclusions}

The literature is rich with reasons for why companies repurchase their own stock, ranging from signalling to being a substitute for cash dividends. Yet managers rarely mention these reasons. Instead, they frequently claim that they are repurchasing shares because prevailing market prices "undervalue" the stock and that it is a "good investment." Despite this public endorsement, the average market response to the news of an open market share repurchase is only 3.5 percent. Such a small reaction seems inconsistent with the undervaluation theme managers are voicing. Either the market ignores a substantial portion of this undervaluation signal or managers have overly optimistic expectations of their firm's value.

We find that, on average, the market underreacts to open market share repurchase announcements. Using a buy-and-hold strategy, four-year abnormal performance following the 
announcement is more than 12 percent. When the announcement and long-run returns are combined, the magnitude of the total undervaluation is about 15 percent, a level more consistent with manager's claims of mispricing.

Undervaluation is an important reason motivating share repurchases, yet other reasons also exist. To distinguish undervaluation from these other motivations, we sort firms on the basis of book-to-market ratios. Repurchases by high book-to-market companies are more likely to be driven by undervaluation, while those with low ratios may be motivated by other reasons. For those cases in which undervaluation is the dominant reason, a more substantial post announcement drift might be expected, even after controlling for overall book-to-market effects in stock returns. For example, Lakonishok, Shleifer and Vishny (1994) show that not all high book-to-market stocks are "true" outof-favor stocks. True out-of-favor stocks will show higher returns in the future compared with high book-to-market stocks in general. High book-to-market firms announcing stock buybacks seem more likely to be truly out-of-favor. This indeed appears to be the case. Firms ranked in the top book-tomarket quintile have four-year abnormal performance of $\mathbf{4 5 . 3}$ percent following the repurchase announcement. This occurs using a benchmark that explicitly controls for size and book-to-market effects in stock returns. This impressive performance cannot be explained by an abnormally high incidence of takeovers. Firms in the bottom two quintiles by book-to-market exhibit abnormal returns close to zero or slightly negative, suggesting that true undervaluation was not a primary motive in these cases. Although book-to-market is closely associated with long-run performance, the initial market reaction to repurchase announcements is surprisingly similar across all book-to-market groups.

This evidence is consistent with other studies which find that managers have market timing ability. A recent paper by Loughran and Ritter (1994) examines the long-run performance of seasoned equity offerings, a corporate action that is the antithesis of a share repurchase. They find evidence of timing ability by observing that managers tend to issue shares when stock prices are high and that the worst long-run performance occurs following periods of heavy offering activity. Seyhun 
(1990) finds that managers successfully timed trades of shares in their own firms following the 1987 crash. We find further evidence that managers possess timing abilities. For some reason, the initial market reaction to management's decision to either issue or remove shares is largely ignored by investors in the short run.

This paper adds to a growing body of literature which finds that the market reaction to news is not always completed over short time periods, an assumption made in many event studies. The full impact of corporate announcements can extend over several years. Other examples of such protracted adjustments include initial as well as seasoned equity offerings, mergers, spinoffs, proxy contests and in a related context, fixed-price repurchase tender offers. Given the diverse settings of this research, serious concerns should be raised as to the appropriateness of measuring abnormal performance over short windows to assess the economic impact of corporate decisions. Why it takes so long is an intriguing issue that requires further work. Some answers to this puzzle are provided by Shleifer and Vishny (1990) who discuss how market inefficiencies can occur in investments with long horizons. 


\section{REFERENCES}

Agrawal, Anup, Jeffrey F. Jaffe and Gershon N. Mandelker, 1992, The post-merger performance of acquiring firms in acquisitions: a re-examination of an anomaly, Journal of Finance 47, 16051621.

Asquith, Paul and David W. Mullins, Jr., 1986, Signalling with dividends, stock repurchases and equity issues, Financial Management 15, 27-44.

Baker, H. Kent, Patricia L. Gallagher and Karen E. Morgan, 1981, Management's view of stock repurchase, Journal of Financial Research 4, 233-247.

Brock, William, Josef Lakonishok and Blake LeBaron, 1992, Simple technical trading rules and the stochastic properties of stock returns, Journal of Finance 47, 1731-1764.

Brown, Stephen J. and Jerold B. Warner, 1980, Measuring security price performance, Journal of Financial Economics 8, 205-258.

Brown, Stephen J. and Jerold B. Warner, 1985, Using daily stock returns: The case of event studies, Journal of Financial Economics 14, 3-31.

Chopra, Navin, Josef Lakonishok, and Jay R. Ritter, 1992, Measuring abnormal performance: Do stocks overreact?, Journal of Financial Economics 31, 235-268.

Comment, Robert, and Gregg A. Jarrell, 1991, The relative signalling power of Dutch auction and fixed price tender offers and open market share repurchases, Journal of Finance 46, 1243-1271.

Constantinides, George M. and Bruce D. Grundy, 1989, Optimal investment with stock repurchase and financing as signals, The Review of Financial Studies, 2, 445-465.

Cusatis, Patrick J., John A. Miles and J. Randall Woolridge, 1993, Restructuring through spinoffs: the stock market evidence, Journal of Financial Economics, 33, 293-311.

Dann, Larry Y., 1981, Common stock repurchases: an analysis of returns to bondholders and stockholders, Journal of Financial Economics 9, 113-138.

Dann, Larry Y., 1983, Is your common stock really worth buying back?, Directors \& Boards 7, no. 4, 23-29.

Fama, Eugene F. and Kenneth R. French, 1992, The cross-section of expected returns, Journal of Finance 47, 427-466.

Fama, Eugene F. and Kenneth R. French, 1993, Common risk factors in the returns on stocks and bonds, Journal of Financial Economics, 33, 3-56.

Gibbons, Michael R., Stephen A. Ross and Jay Shanken, 1989, A test of the efficiency of a given portfolio, Econometrica 57, 1121-1152. 
Ikenberry, David and Josef Lakonishok, 1993, Corporate governance through the proxy contest: Evidence and implications, Journal of Business, 66, 405-435.

Lakonishok, Josef, Andrei Shleifer and Robert W. Vishny, 1994, Contrarian investing, extrapolation and risk, forthcoming, Journal of Finance.

Lakonishok, Josef and Theo Vermaelen, 1990, Anomalous price behavior around repurchase tender offers, Journal of Finance, 455-477.

Loughran, Tim and Jay R. Ritter, 1994, The new issues puzzle, forthcoming, Journal of Finance.

Ofer, Aharon R. and Anjan V. Thakor, 1987, A theory of stock price response to alternative corporate disbursement methods: stock repurchases and dividends, Journal of Finance 42, 365394.

Ritter, Jay R., 1991, The long-run performance of initial public offerings, Journal of Finance 46, 127.

Seyhun, H. Nejat, 1990, Overreaction or fundamentals: Some lessons from insiders' response to the market crash of 1987, Journal of Finance 45, 1363-1388.

Shleifer, Andrei and Robert W. Vishny, 1990, Equilibrium short horizon of investors and firms, American Economic Review 80, 148-153.

Vermaelen, Theo, 1981, Common stock repurchases and market signalling, Journal of Financial Economics 9, 139-183.

Wansley, James W., William R. Lane and Salil Sarkar, 1989, Management's view of share repurchase and tender premiums, Financial Management 18, 97-110. 
Table 1

\section{Descriptive Statistics for \\ Open Market Share Repurchase Announcements Between January 1980 to December 1990}

This table reports the number of open market share repurchases announced in the Wall Street Journal by year for ASE, NYSE and NASDAQ firms, the dollar value of these announcements, the percent of shares announced for repurchase, and the size decile rank of the firms when the announcement was made. In some cases, firms did not state the number of shares they intended to repurchase. Size decile rankings are determined relative to all ASE and NYSE firms on the annual industrial Compustat tape in the month prior to the repurchase announcement, where the smallest firms are ranked in decile 1.

\begin{tabular}{|c|c|c|c|c|c|c|c|c|c|c|c|c|c|}
\hline \multirow[b]{2}{*}{ Year } & \multirow[b]{2}{*}{$\mathbf{n}$} & \multirow[b]{2}{*}{$\begin{array}{c}\$ \\
\text { (Billion) }\end{array}$} & \multirow{2}{*}{$\begin{array}{r}\text { Mean \% } \\
\text { of Shares } \\
\text { Announced }\end{array}$} & \multicolumn{5}{|c|}{$\begin{array}{l}\text { Percent of Shares Announced } \\
\text { For Repurchase }\end{array}$} & \multicolumn{5}{|c|}{$\begin{array}{l}\text { Size Decile Rank } \\
\text { At Announcement }\end{array}$} \\
\hline & & & & $\begin{array}{l}0 \text { to } \\
2.5 \%\end{array}$ & $\begin{array}{l}2.5 \text { to } \\
5 \%\end{array}$ & $\begin{array}{l}5 \text { to } \\
10 \%\end{array}$ & $\begin{array}{r}\text { Above } \\
10 \% \\
\end{array}$ & $\begin{array}{c}\text { Not } \\
\text { Stated }\end{array}$ & $\begin{array}{l}\text { Small } \\
1-2\end{array}$ & $3-4$ & $5-6$ & $7-8$ & $\begin{array}{r}\text { Large } \\
9-10 \\
\end{array}$ \\
\hline 1980 & 86 & 1.429 & 4.73 & 31 & 20 & 27 & 6 & 2 & 9 & 15 & 16 & 18 & 28 \\
\hline 1981 & 95 & 3.013 & 5.24 & 29 & 26 & 23 & 13 & 4 & 13 & 12 & 16 & 21 & 33 \\
\hline 1982 & 128 & 3.106 & 5.74 & 25 & 38 & 42 & 18 & 5 & 22 & 14 & 35 & 21 & 33 \\
\hline 1983 & 43 & 1.645 & 5.05 & 11 & 18 & 9 & 3 & 2 & 5 & 4 & 6 & 10 & 18 \\
\hline 1984 & 203 & 10.105 & 5.57 & 34 & 78 & 53 & 24 & 14 & 35 & 39 & 50 & 28 & 51 \\
\hline 1985 & 113 & 14.380 & 7.45 & 22 & 30 & 34 & 24 & 3 & 16 & 23 & 17 & 18 & 39 \\
\hline 1986 & 145 & 17.189 & 7.12 & 30 & 36 & 37 & 33 & 9 & 17 & 27 & 26 & 29 & 46 \\
\hline $1987^{*}$ & 92 & 27.380 & 7.92 & 14 & 20 & 31 & 26 & 1 & 10 & 15 & 14 & 18 & 35 \\
\hline 1988 & 121 & 14.967 & 7.15 & 20 & 30 & 38 & 26 & 7 & 17 & 15 & 23 & 24 & 42 \\
\hline 1989 & 117 & 31.971 & 8.53 & 18 & 28 & 35 & 33 & 3 & 14 & 15 & 17 & 24 & 47 \\
\hline 1990 & 96 & 17.403 & 7.84 & 10 & 28 & 37 & 21 & 0 & 14 & 18 & 15 & 18 & 31 \\
\hline All Years & 1,239 & 142.587 & 6.64 & 244 & 352 & 366 & 227 & 50 & 172 & 197 & 235 & 229 & 406 \\
\hline
\end{tabular}

${ }^{*}$ Excludes all announcements made in the fourth quarter. 
Table 2

\section{Abnormal Returns On and Around the Announcement of Open Market Share Repurchases 1980 to 1990}

The table reports abnormal returns (in percent) measured with respect to the CRSP equal-weighted index over days -20 to $-11,-10$ to $-3,-2$ to +2 , and +3 to +10 relative to the announcement of an open market share repurchase made during the period January 1980 through December 1990 ( $t$-statistics reported in parentheses). Abnormal returns are reported for all sample firms and by time period, the percentage of shares announced for repurchase, the reason stated by the company for the repurchase (if any), the size decile rank and the book-to-market quintile rank in the month prior to announcement.

\begin{tabular}{lcccccrr} 
& \multicolumn{7}{c}{ Days Relative to Repurchase Announcement } \\
\cline { 2 - 7 } & $\mathrm{n}$ & -20 to -3 & -2 to +2 & +3 to +10 \\
\hline All Firms & 1.239 & -3.07 & $(-9.91)$ & 3.54 & $(21.72)$ & .21 & $(1.00)$ \\
Time Period & & & & & & & \\
\hline 1980 to 1983 & 352 & -3.59 & $(-6.40)$ & 4.25 & $(14.37)$ & 0.91 & $(2.42)$ \\
1984 to 1986 & 461 & -2.86 & $(-6.47)$ & 4.12 & $(17.71)$ & -0.03 & $(-0.09)$ \\
1987 to 1990 & 426 & -2.86 & $(-5.79)$ & 2.33 & $(8.94)$ & -0.12 & $(-0.36)$ \\
\hline
\end{tabular}

\begin{tabular}{|c|c|c|c|c|c|c|c|}
\hline \multicolumn{8}{|c|}{ Percent Intended to Repurchase } \\
\hline 0 to $2.5 \%$ & 241 & -4.68 & $(-8.11)$ & 2.58 & $(8.50)$ & 0.77 & $(2.00)$ \\
\hline 2.5 to $5 \%$ & 335 & -4.01 & $(-7.78)$ & 2.87 & $(10.54)$ & 0.12 & $(0.34)$ \\
\hline 5 to $10 \%$ & 367 & -2.80 & $(-5.22)$ & 3.86 & $(13.64)$ & 0.11 & $(0.30)$ \\
\hline At or above $10 \%$ & 246 & -0.59 & $(0.83)$ & 4.51 & $(12.02)$ & -0.24 & $(-0.52)$ \\
\hline Not Disclosed & 50 & -3.09 & $(-2.01)$ & 5.57 & $(6.88)$ & 1.03 & $(1.01)$ \\
\hline \multicolumn{8}{|l|}{ Stated Reason } \\
\hline Undervalued & 38 & -5.52 & $(-3.38)$ & 5.31 & $(6.17)$ & -1.29 & $(-1.18)$ \\
\hline Anti-takeover & 7 & 6.79 & $(2.09)$ & 5.50 & (3.21) & 3.76 & $(1.74)$ \\
\hline ESOP or Stock Option & 82 & -1.69 & $(-1.70)$ & 3.00 & $(5.71)$ & 0.24 & $(0.36)$ \\
\hline Acquisition & 9 & -3.87 & $(-1.39)$ & 2.56 & $(1.75)$ & 1.49 & $(0.80)$ \\
\hline General Corp. Purposes & 16 & -1.32 & $(-0.67)$ & 1.83 & $(1.77)$ & 2.27 & $(1.73)$ \\
\hline Other & 27 & -2.79 & $(-1.73)$ & 2.52 & $(2.98)$ & -1.19 & $(-1.11)$ \\
\hline Not Disclosed & 1060 & -3.18 & $(-9.57)$ & 3.57 & $(20.40)$ & 0.23 & $(1.03)$ \\
\hline \multicolumn{8}{|l|}{ Size Decile } \\
\hline 1-2 (Small Firms) & 172 & -3.91 & $(-3.12)$ & 8.19 & $(12.41)$ & 0.70 & $(0.83)$ \\
\hline $3-4$ & 197 & -5.71 & $(-6.62)$ & 4.67 & $(10.27)$ & -0.76 & $(-1.32)$ \\
\hline $5-6$ & 235 & -2.99 & $(-4.50)$ & 3.08 & $(8.79)$ & 0.20 & $(0.46)$ \\
\hline $7-8$ & 229 & -3.53 & $(-6.08)$ & 2.13 & $(6.96)$ & 0.70 & $(1.80)$ \\
\hline 9-10 (Large Firms) & 406 & -1.21 & $(-3.61)$ & 2.09 & $(11.84)$ & 0.19 & $(0.86)$ \\
\hline \multicolumn{8}{|l|}{ Book-to-Market Quintile } \\
\hline 1 (Glamour Stocks) & 201 & -3.53 & $(-3.78)$ & 3.36 & (6.84) & 0.11 & $(0.18)$ \\
\hline 2 & 260 & -4.30 & $(-6.72)$ & 3.14 & $(9.32)$ & 0.48 & $(1.12)$ \\
\hline 3 & 276 & -2.72 & $(-4.50)$ & 4.07 & $(12.80)$ & 0.15 & $(0.37)$ \\
\hline 4 & 230 & -2.54 & $(-4.06)$ & 3.46 & $(10.51)$ & 0.21 & $(0.49)$ \\
\hline 5 (Value Stocks) & 241 & -2.17 & $(-3.76)$ & 3.56 & $(11.71)$ & 0.07 & $(0.18)$ \\
\hline
\end{tabular}


Table 3

\section{Annual Buy and Hold Returns Following \\ Open Market Share Repurchase Announcements 1980 to 1990}

This table reports annual and compounded buy-and-hold returns (in percent) following open market share repurchase announcements for up to four years. Equal-weighted portfolios are formed for all announcements between 1980 and 1990 and for two sub-periods, 1980 through 1985 and 1986 through 1990. The reference portfolio is formed using benchmark returns corresponding to the repurchase sample, matched on the basis of size and book-to-market ranking. Compounded holding period returns assume annual rebalancing. Significance levels are determined via bootstrapping.

\begin{tabular}{|c|c|c|c|c|c|c|c|c|c|}
\hline & \multicolumn{5}{|c|}{ Annual Buy and Hold Returns } & \multicolumn{4}{|c|}{ Compounded Holding Period Returns } \\
\hline & \multicolumn{3}{|c|}{ Repurchase Reference } & \multirow{2}{*}{\multicolumn{2}{|c|}{ Diff. (p-value) }} & \multirow{2}{*}{\multicolumn{2}{|c|}{ Repurchase Reference }} & \multirow[b]{2}{*}{ Diff. } & \multirow[b]{2}{*}{ (p-value) } \\
\hline & $\mathrm{n}$ & Firms & Portfolio & & & & & & \\
\hline \multicolumn{10}{|c|}{ All Firms } \\
\hline Year 1 & 1208 & 20.80 & 18.76 & 2.04 & .064 & 20.80 & 18.76 & 2.04 & .064 \\
\hline Year 2 & 1188 & 18.12 & 15.81 & 2.31 & .098 & 42.69 & 37.53 & 5.16 & .011 \\
\hline Year 3 & 1047 & 21.77 & 17.18 & 4.59 & .002 & 73.75 & 61.15 & 12.60 & .000 \\
\hline Year 4 & 893 & 8.56 & 9.51 & -0.96 & .892 & 88.62 & 76.48 & 12.14 & .012 \\
\hline \multicolumn{10}{|c|}{1980 to 1985} \\
\hline Year 1 & 646 & 32.36 & 28.89 & 3.47 & .029 & 32.36 & 28.89 & 3.47 & .029 \\
\hline Year 2 & 637 & 25.23 & 21.76 & 3.47 & .017 & 65.75 & 56.93 & 8.82 & .002 \\
\hline Year 3 & 615 & 21.79 & 18.43 & 3.36 & .035 & 101.87 & 85.85 & 16.02 & .000 \\
\hline Year 4 & 583 & 10.38 & 12.07 & -1.68 & .938 & 122.83 & 108.28 & 14.55 & .024 \\
\hline \multicolumn{10}{|c|}{1986 to 1990} \\
\hline Year 1 & 562 & 7.52 & 7.11 & 0.41 & .444 & 7.52 & 7.11 & .41 & .444 \\
\hline Year 2 & 551 & 9.91 & 8.93 & 0.97 & .338 & 18.17 & 16.68 & 1.49 & .349 \\
\hline Year 3 & 432 & 21.73 & 15.39 & 6.34 & .008 & 43.85 & 34.64 & 9.21 & .032 \\
\hline Year 4 & 310 & 5.12 & 4.71 & 0.41 & .531 & 51.22 & 40.98 & 10.24 & .092 \\
\hline
\end{tabular}


Table 4

\section{Annual and Compounded Buy-and-Hold Returns by Book-to-Market Quintile Following Open Market Share Repurchase Announcements 1980 to 1990}

This table reports annual and compounded buy-and-hold returns (in percent) for equal-weighted portfolios of firms announcing open market share repurchases up to four years following an open market share repurchase announcement by book-to-market quintile ranking. Ranks are determined by sorting all NYSE and ASE firms on the annual industrial Compustat tape into size deciles. Each decile is further sorted into quintiles on the basis of book-to-market, with the lowest ratios assigned to quintile 1. Firms which could not be ranked at the time of the announcement are excluded. The reference portfolio comprises benchmark returns matched to the repurchase sample on the basis of size and book-to-market. Compounded holding period returns assume annual rebalancing. Significance levels are determined via bootstrapping.

Annual Buy and Hold Returns

Repurchase Reference

Firms Portfolio

Book-to-Market Quintile 1 (Glamour Stocks)

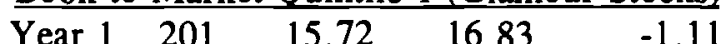

Year 2195

Year 3184

17.86

16.60

12.00

13.61

4.98
6.42
$-1.11$

1.26

$-1.61$
Compound Holding Period Returns Repurchase Reference Firms Portfolio

15.72

36.40

52.77

60.38

.687
.136
.568
.330

16.83

36.22

54.75

64.69 Diff. (p-value)

Book-to-Market Quintile 2

\begin{tabular}{rrrrrrrrrr} 
Year 1 & 260 & 20.59 & 18.43 & 2.16 & .206 & 20.59 & 18.43 & 2.16 & .206 \\
Year 2 & 250 & 12.34 & 15.07 & -2.73 & .487 & 35.47 & 36.28 & -0.81 & .625 \\
Year 3 & 223 & 22.39 & 17.29 & 5.10 & .070 & 65.80 & 59.84 & 5.96 & .220 \\
Year 4 & 191 & 3.20 & 6.99 & -3.79 & .668 & 71.10 & 71.02 & 0.08 & .498 \\
\hline
\end{tabular}

Book-to-Market Quintile 3

\begin{tabular}{rrrrrrrrrr}
\hline Year 1 & 276 & 19.49 & 16.46 & 3.03 & .087 & 19.49 & 16.46 & 3.03 & .087 \\
Year 2 & 268 & 18.23 & 17.33 & 0.90 & .487 & 41.27 & 36.64 & 4.63 & .174 \\
Year 3 & 225 & 20.77 & 16.57 & 4.20 & .070 & 70.61 & 59.29 & 11.32 & .058 \\
Year 4 & 184 & 7.45 & 10.35 & -2.90 & .635 & 83.32 & 75.78 & 7.54 & .308 \\
\hline
\end{tabular}

\section{Book-to-Market Ouintile 4}

\begin{tabular}{rrrrrrrrrr}
\hline Year 1 & 230 & 23.43 & 22.84 & 0.59 & .374 & 23.43 & 22.84 & 0.59 & .374 \\
Year 2 & 228 & 15.16 & 12.73 & 2.43 & .178 & 42.14 & 38.48 & 3.66 & .197 \\
Year 3 & 198 & 24.05 & 18.32 & 5.73 & .067 & 76.32 & 63.85 & 12.47 & .058 \\
Year 4 & 172 & 12.44 & 11.06 & 1.38 & .567 & 98.24 & 81.97 & 16.27 & .144 \\
\hline
\end{tabular}

Book-to-Market Quintile 5 (Value Stocks)

\begin{tabular}{llllllllll} 
Year 1 & 241 & 24.15 & 19.49 & 4.66 & .054 & 24.15 & 19.49 & 4.66 & .054 \\
Year 2 & 234 & 26.01 & 17.23 & 8.78 & .003 & 56.44 & 40.08 & 16.36 & .003 \\
Year 3 & 199 & 29.81 & 20.49 & 9.32 & .013 & 103.07 & 68.78 & 34.29 & .000 \\
Year 4 & 169 & 16.17 & 12.94 & 3.23 & .389 & 135.91 & 90.62 & 45.29 & .000 \\
\hline
\end{tabular}


Table 5

\section{Fama-French Three-Factor Model Regression Coefficients}

Below are coefficients obtained from regressing excess monthly portfolio returns on the following threefactor model as suggested by Fama and French (1993):

$$
r_{p, t}-r_{f, t}=\alpha+\beta_{m}\left(r_{m, t}-r_{f, t}\right)+\beta_{s}\left(r_{\text {small }, t}-r_{\text {large }, t}\right)+\beta_{b m}\left(r_{\text {high }, t}-r_{\text {low }, t}\right)+\epsilon_{t}
$$

where $r_{p, t}-r_{f, t}$ is the excess portfolio return in month $t,\left(r_{m, t}-r_{f, t}\right)$ is an overall market factor formed by calculating the excess portfolio return to a value weighted portfolio of NYSE, ASE and NASDAQ firms.

$r_{\text {small, } t}-r_{\text {large, } t}$ is a size factor. It is measured as the difference in month $t$ returns between two valueweighted portfolios composed of those stocks with market equity values below the median NYSE firm and those with market equity values above the median NYSE firm. $r_{\text {high,t }}-r_{\text {low,t }}$ is a book-to-market factor. It is measured as the difference in month $t$ returns between two value-weighted portfolios, one containing firms ranked among the 30 percent of NYSE firms with the highest book-to-market ratios and the other containing firms ranked among the 30 percent of NYSE firms with the lowest book-to-market ratios. Portfolios are formed in calendar-time. We assume that sample firms are bought at the end of the month in which an open market repurchase announcement is made. New firms are added each month as announcements occur and are removed 36 months following the announcement. Portfolios are formed by book-to-market rank at the time of the announcement for repurchase announcements between 1980 and 1990. Because of small samples during the initial months, portfolio returns obtained for the first six months of 1980 are ignored.

Book-to

\begin{tabular}{|c|c|c|c|c|c|}
\hline Market Rank & $\alpha$ & $\underline{\beta}_{\mathrm{m}-}$ & $\underline{\beta}_{s-}$ & $\beta_{\mathrm{bm}}$ & $\mathrm{R}^{2}$ \\
\hline 1 (Glamour Stocks) & $\begin{array}{c}-0.30 \\
(t=-1.23)\end{array}$ & 1.04 & 0.86 & 0.02 & 80.3 \\
\hline 2 & $(t=0.45)$ & 1.06 & 0.59 & 0.00 & 90.3 \\
\hline 3 & $\left(\mathrm{t}=\begin{array}{l}0.12 \\
0.93)\end{array}\right.$ & 1.03 & 0.67 & 0.28 & 92.3 \\
\hline 4 & $(t=0.97)$ & 1.00 & 0.62 & 0.34 & 90.3 \\
\hline 5 (Value Stocks) & $\begin{array}{c}0.43 \\
(\mathrm{t}=3.30)\end{array}$ & 1.08 & 0.62 & 0.42 & 92.1 \\
\hline
\end{tabular}




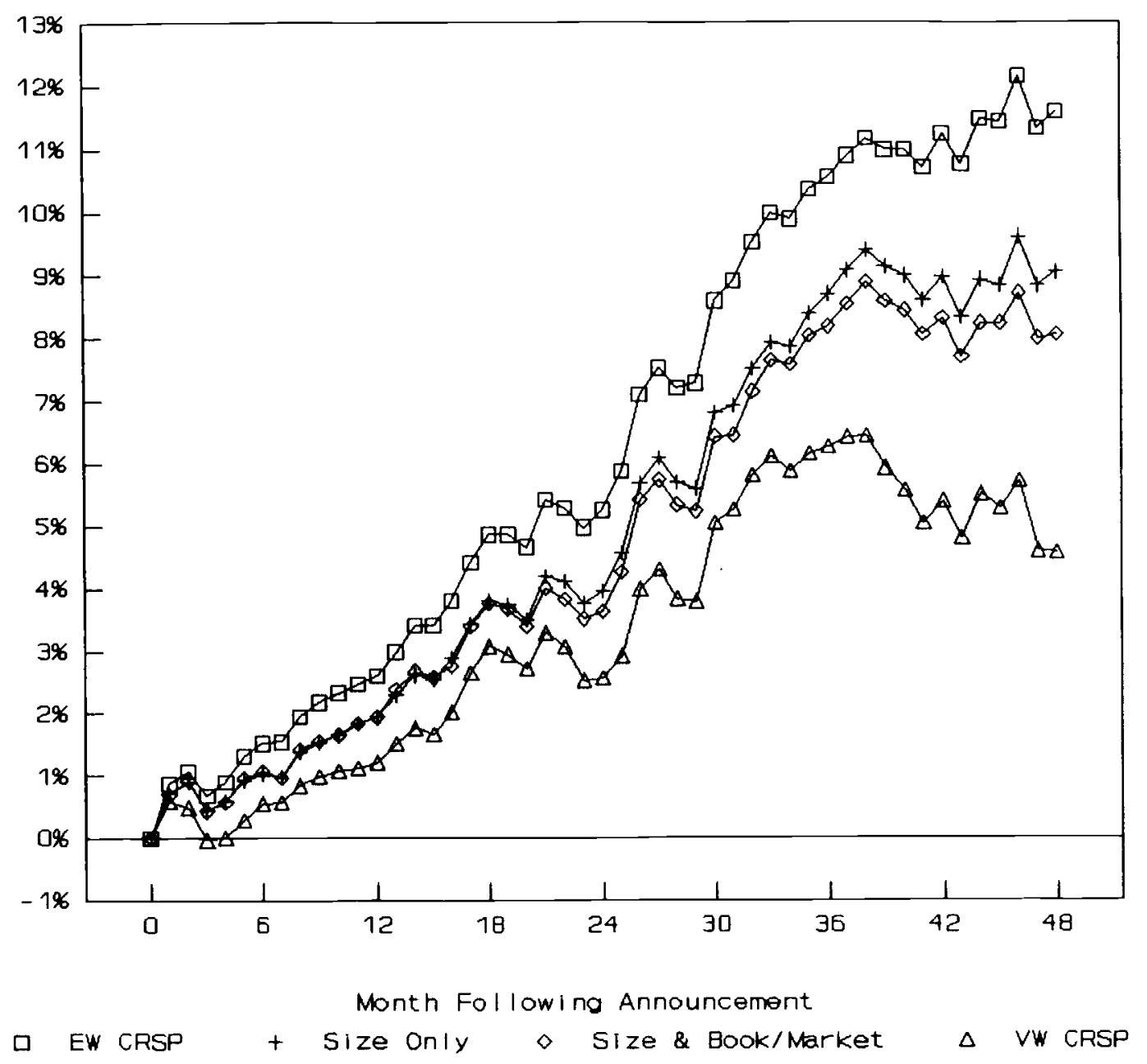

Figure 1. Comparative Monthly Cumulative Abnormal Returns Following Open Market Share Repurchase Announcements, 1980 -1990. This figure plots the cumulative abnormal return (CAR) up to 48 months following the announcement of an open market share repurchase. Abnormal returns are calculated using four different methods; market adjusted returns using the CRSP equal-weighted index of ASE and NYSE firms (EW CRSP), size-adjusted returns using equal-weighted portfolio returns of NYSE and ASE firms from the same size decile (Size Only), and size and book-to-market adjusted returns using equal-weighted portfolio returns of NYSE and ASE firms from the same size decile and bookto-market quintile (Size and Book/Market), and market adjusted returns using the CRSP value-weighted index of NYSE and ASE firms (VW CRSP). 


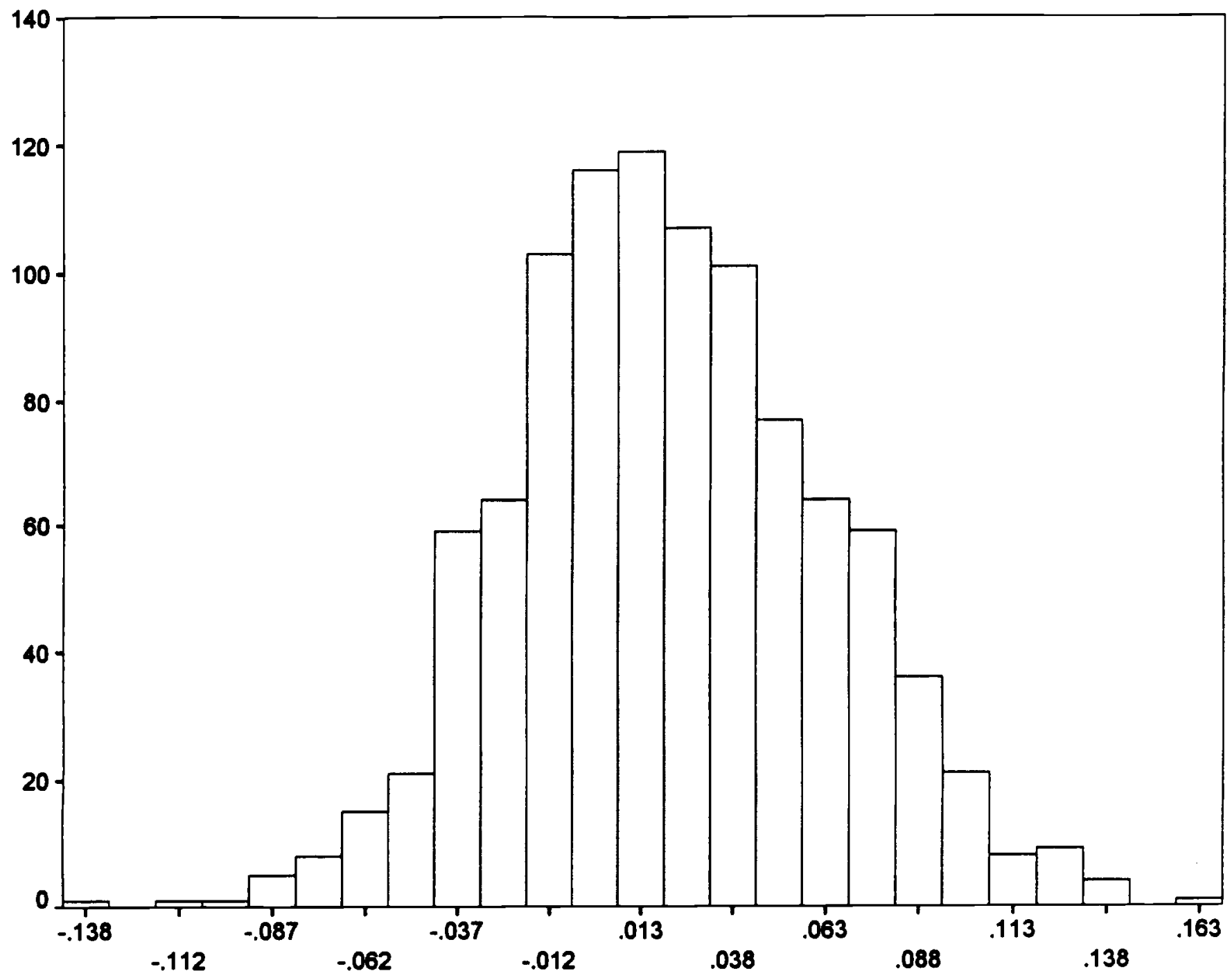

Figure 2. Compounded Four-Year Abnormal Performance Adjusted for Size and Book-to-Market Under the Null Hypothesis for Open Market Share Repurchase Announcements Between January 1980 and December 1990. This histogram plots the empirical distribution of four-year compounded abnormal returns for 1,000 bootstrap portfolios specific to our sample of repurchase announcements. Each portfolio is formed by taking the post-announcement returns for a given sample firm and replacing them with the returns to a firm randomly chosen from the NYSE or ASE having the same size and bookto-market classification at that point in time. This is done for each firm in the sample to form a single portfolio. This entire process is then repeated until 1,000 such portfolios are formed. The compounded abnormal performance from these randomly formed portfolios provides us with an empirical estimate of the distribution relevant to the entire sample of repurchase announcements in our study. The empirical distributions for sub-samples are unique and are therefore estimated separately. 